"Factors affecting youth entrepreneurship development within Kibera, Kenya: the perspective of entrepreneurship education"

AUTHORS Wise Sambo

Wise Sambo (2016). Factors affecting youth entrepreneurship development

ARTICLE INFO within Kibera, Kenya: the perspective of entrepreneurship education. Problems and Perspectives in Management, 14(2-2), 331-338. doi:10.21511/ppm.14(22).2016.09

DOI http://dx.doi.org/10.21511/ppm.14(2-2).2016.09

RELEASED ON Monday, 13 June 2016

JOURNAL

"Problems and Perspectives in Management"

FOUNDER

LLC "Consulting Publishing Company "Business Perspectives"

NUMBER OF REFERENCES

0

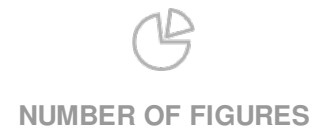

0

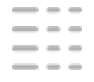

NUMBER OF TABLES

0

(C) The author(s) 2023. This publication is an open access article. 
Wise Sambo (South Africa)

\title{
Factors affecting youth entrepreneurship development within Kibera, Kenya: the perspective of entrepreneurship education
}

\begin{abstract}
All over the world there has been an increased interest in entrepreneurship education and the society in general. Kenya was among the first countries in Africa to introduce aspects of entrepreneurship education in its education and training systems. Entrepreneurship and business creation are a growing alternative for young people in different economies whose age group often faces a labor market with double digit unemployment rates. This study seeks to investigate and report on the factors affecting youth entrepreneurship development with specific reference to entrepreneurship education in Kibera, a district of Kenya. Two objectives are identified, namely (i) to determine the government's provision and access to the entrepreneurship education and training among the Kenyan youth, and (ii) to determine whether there is a relationship between the level of education, training and development of youth entrepreneurship. A sample of three hundred entrepreneurs (aged 18-35) within the Kibera district in Kenya is drawn to participate in this study. Structured survey questionnaires are used to collect primary data from business owners in the Kibera district. Findings revealed a strong positive correlation between the provision of entrepreneurship education and development of youth entrepreneurship and the level of education has a very weak positive correlation to youth entrepreneurship development. This study concludes with recommendations on how youth entrepreneurship can be improved in Kibera and the rest of Kenya. A total of 300 questionnaires were administered via emails with a total response rate of $83.3 \%$ (250) returned for analysis.
\end{abstract}

Keywords: youth entrepreneurship, unemployment, Kibera, entrepreneurship education.

JEL Classification: E24, L26.

\section{Introduction}

Since independence, the role of youth in Kenya has been largely peripheral leading to their current marginalization manifested in the form of unemployment, crime, drug abuse and passive involvement in constructive nation building (Rori, Bunei \& Mwenzwa, 2011). Globally, youth unemployment was estimated to be $12.6 \%$ in 2013 and projected to increase to $12.7 \%$ in 2014 (Global employment Trend for Youth, 2013). In developed and Sub-Saharan African countries, youth unemployment was, respectively, 18.1 and $11.8 \%$, on average during 2012 (Global employment Trend for Youth, 2013). While in Kenya, youth unemployment constituted $70 \%$ of total unemployment in 2007 (Kilele, 2008). On the other hand, South Africa's youth unemployment rate was estimated to be at $31.4 \%$ in 2013 (Statistics South Africa, 2014) which evidence the huge challenges that African countries face as far as young people are concerned. Like for any other developing nation, entrepreneurship and small business are the critical source of new jobs and economic dynamism to improve youth livelihoods and, also, their economic independence. According to Njoroge and Gathungu (2013), one of Africa's greatest limitations to economic development can be ascribed to its lack of entrepreneurs. Kshetri (2011) argued that Africans were entrepreneurial before colonization, but slowed down in the colonial period. Nevertheless, there

(C) Wise Sambo, 2016.

Wise Sambo, M.Tech., Economic and Management Sciences, Department of Business Management, University of South Africa, South Africa. have been many successful entrepreneurs in Africa. Of late, entrepreneurship development in Kenya has been primarily focused on youth in technical training institutions and expanded to include the universities. Programs are intended at introducing youth to entrepreneurship education with the aim of getting them to think about entrepreneurship and the role of business entrepreneurs in economic development. They also get an opportunity to analyze the difficult employment situation in Kenya and are encouraged to consider self-employment as a career choice (Kaburi, Mobegi, Kombo, Omari \& Sewe, 2012). Entrepreneurship and business creation are seen as a growing alternative for young people in Kenya (Kibera, in particular) whose age group often faces a labor market with double digit unemployment rates. For young people in the informal economy, micro-entrepreneurism is a bottom-up method for generating an income, selfreliance and a new innovative path to earning a living and caring for oneself (Maxwell, 2002). Albeit, it is recorded that a growing number of young people are taking up the challenge of starting their own business in Kenya and much is being learned about how the odds for success can be improved through various types of assistance and through the creation of a supportive environment" (Somavia, in Ulrich Schoof, 2006).

\section{Research problem statement}

The youth represent $43 \%$ of the working age population in Kenya and constitute $70 \%$ of total unemployment (Kilele, 2008). The youths in Kenya face vital challenges, particularly in the economic 
context of livelihoods (Omondi, 2013). A large population of young people is without work and many more are engaged in short-term, low-paid jobs or in the informal economy. Despite the fact that Kenya remains focused to achieve its Vision 2030, decent work can also shift young people from social dependence to self-sufficiency and escape from poverty. Entrepreneurship education can be seen to inform the best alternative to youth in accessing decent work and creating more job opportunities for others. Notwithstanding this universally agreed fact, the rate of young Kenyans starting successful enterprises is minimal. Poor economic participation of young people inhibits the country's economic development and high dependency on the working population. In this study, two objectives were sought to be appropriate to:

- determine the government's provision of and access to the entrepreneurship education and training among the Kenyan youth; and to

- determine whether there is a relationship between the level of education, training and development of youth entrepreneurship.

Furthermore, two hypothetical statements below were formulated and tested using descriptive statistics.

1. $H_{0}$ (null hypothesis): There is no relationship between provision of entrepreneurship education \& training and the development of youth entrepreneurship.

$H_{1}$ (alternative hypothesis): There is a relationship between provision of entrepreneurship education \& training and the development of youth entrepreneurship.

2. $H_{0}$ (null hypothesis): There is no relationship between the level of education, training and the development of youth entrepreneurship.

$H_{1}$ (alternative hypothesis): There is a relationship between the level of education \& training and youth entrepreneurship development.

\section{Literature review}

Many countries, regardless of their level of development, have introduced entrepreneurship in their education and training system (Simiyu \& Sambu, 2012). In Africa, Kenya was among the first to introduce aspects of entrepreneurship education in its education and training systems. Nonetheless, Kenya has also experienced high population growth where approximately $40 \%$ of the total population lies within the primary and secondary education age bracket (Zepeda, 2013). This has implications on the provision of education and training with respect to services and employment opportunities. The formal sector has not met the challenges of employment creation. Approximately 500,000 graduates from various tertiary academic institutions enter the job market annually in Kenya (Kaane, 2014). However, due to low economic growth, rampant corruption, nepotism and demand for experience by potential employees, a majority of youth remains unemployed (Kenya National Youth Policy, 2012). To address youth problems and, more specifically, unemployment and empowerment, efforts have been made by the Government to initiate Youth Development Programs through policy documents such as Sessional Paper Number 4 of 2005, Sessional Paper Number 2 of 1992 on Small Scale and Jua Kali Enterprises, Development Plan 1997-2001, and the Poverty Eradication Plan 1999-2015, among others (Okirigiti \& Rafey, 2015). The Youth Enterprise Development Fund (YEDF) was conceived by the government in June 2006 as a strategic move toward arresting unemployment among the youth in Kenya. This fund was established to achieve the following objectives: to provide loans to existing micro-finance institutions (MFIs), registered non-governmental organizations (NGOs) involved in micro-financing, and savings and credit co-operative organizations (SACCOS) for lending to youth enterprises; to attract and facilitate investment in micro, small and medium enterprises, oriented commercial infrastructure such as business or industrial parks, and markets or business incubators that will be beneficial to youth enterprises; to support youth-oriented micro, small and medium enterprises to develop linkages with large enterprises; to facilitate marketing of products and services of youth enterprises in both domestic and international markets; to facilitate employment of youth in the international labor market (Kanyari \& Namusonge, 2013). Data from the Ministry of Trade indicate that the micro, small and medium enterprise sector provides employment to over 5 million of the Kenyan workforce and contributes to about $18.4 \%$ of the GDP (Njoroge \& Gathungu, 2013).

\section{The concept of youth entrepreneurship}

The Kenya National Youth policy (2012) has defined youth as those individuals aged between 1830 years. This definition takes into account the physical, psychological, cultural, social, biological and political aspects, which explain the Kenyan youth situation. However, the new Constitution defines youth as all individuals in the Republic of Kenya who have reached the age of 18 years but have not attained the age of 35 years (GOK, 2010). According to Chigunta, Schnurr \& James-Wilson (2005), youth entrepreneurship is the practical application of enterprising qualities, such as initiative, innovation, creativity, and risk-taking into the work environment (either in self-employment or employment in small start-up firms), using the appropriate skills necessary for success in that environment and culture by individuals within the 
youth age group bracket (18-35). As indicated earlier in the study, entrepreneurship development in Kenya is recently aimed at youth, as can be seen in many technical and vocational institutions and even expanded to universities (Kaburi et al., 2012).

3.1. Youth entrepreneurship development in Kenya. Entrepreneurship has been proven to be beneficial for economic growth, job creation and poverty alleviation (Chiloane-Tsoka \& Mmako, 2014). Though, Africa still has a lot of catch-up to do. Narratively, in South Africa, government sponsored initiatives targeted at supporting youth entrepreneurs include institutions such as the National Youth Development Agency (NYDA), whereas, in Kenya, one of the first efforts to move in the new direction to entrepreneurial development involved introducing entrepreneurship education into all technical training institutions in the country. Various programs by the government of Kenya such as Youth and Women Enterprise Development Fund have been put in place to facilitate the creation of entrepreneurial ventures (Sagwe, Gicharu \& Mahea, 2011). The Ministry of State for Youth Affairs in partnership with various private financial intermediaries is administering the Youth Enterprise Development Fund to the youth (Moraa New Hope Foundation, 2015). This fund has been specifically tailored to enhance the youth to develop with focus on self-employment via entrepreneurship initiatives. Youth can access these funds either individually or in groups, and the collateral to secure the money borrowed has been made affordable in the sense that it can be in a form of group guarantee, guarantee by parents, relatives or even community leaders. With these eased regulations, Moraa New Hope Foundation (2015) hopes that youth in the country will be able to work towards the realization of their life goals that were hindered by the tough regulations that have in the past barred them from accessing credit facilities. However, these initiatives are not without challenges. Recently, substandard institutions have come up to take advantage of shortage of training opportunities to exploit desperate youth (Kimando, Njogu \& Kihoro, 2012). Similarly, in South Africa it was found that none of the provincial departments, municipalities and metros as well as most national agencies had conceptual frameworks on small business development to guide their activities (Mazwai, 2012). Furthermore, Mazwai (2012) argued that local economic development framework was deprived to stimulate communities, and the state did not give strong leadership.

3.2. Barriers that hinder youth entrepreneurship development in Kenya. This study uses the term "challenge" interchangeably with "barriers" throughout the paper depending on how different authors have reported their research in the literature. The challenges facing youth in Kenya are best summarized in the Proceedings of a stakeholder workshop on youth and development organized by the World Bank on 11th March 2004 that recorded a number of challenges affecting youth in Kenya (cited in Kaburi et al., 2012). The workshop had 29 participants from Youth Organizations, World Bank, United Nations and the Government. Below some of the potential barriers are identified that affect entrepreneurship development in Kenya:

- Access to credit. Literature, in a recent study conducted by Sambo (2015), showed a moderate positive correlation between access to credit and the development of youth entrepreneurship. This study concurs with the study by Mwangi \& Shem (2012) that accessing credit is a major constraint to the development and growth of small and micro enterprises (SMEs) and, also, to poor rural and urban households. However, this study focuses on the provision of entrepreneurship education and the relationship between level of education and youth entrepreneurship development.

- Entrepreneurship education. Governments around the world have shown a growing interest in interventions that promote entrepreneurial success, making significant investments in entrepreneurship education and training (Valerio, Parton \& Robb, 2014). This is happening not only in developed nations, but also across the developing world as well. According to Njongeri (2015), there is a limited access to secondary schools, and alternative forms of education are lacking in Kibera and the rest of Kenya. There is also a need for life skills training in the education curriculum. At present, students are trained just to pass exams (Kaburi et al., 2012). Globally, entrepreneurship education and training research is unable to draw a direct causal link connecting the enhanced knowledge with the subsequent performance of enterprises (Valerio, Parton \& Robb, 2014).

- Society's attitude towards youth. Youth faces discrimination purely on the grounds of age (Kaburi, 2013). According to Kaburi et al. (2012), this is legitimatized by beliefs as that wisdom only comes with age, and that youth is merely a transition period. Society also perceives youth as irresponsible and troublemakers (Mahinda, 2004). This perception may contribute to difficulty in obtaining credit. Most economies support entrepreneurship education and training so as to encourage their citizens to demonstrate positive attitude towards self-employment, identify viable business opportunities, portray a desire to venture into business, demonstrate managerial skills for 
running successful enterprises, encourage new start-ups and other entrepreneurial ventures (Njoroge \& Gathungu, 2013).

- Expectations of youth. In Kenya, society's, expectations of young people are not very clear (Kaburi et al., 2012). According to Kenya Voluntary Development Association (KVDA) (2015), a gap in expectations has opened between what parents and older generations expect of youth, on the one hand, and the expectations of youth themselves (influenced by their peers, the media, etc.), on the other, furthermore, society's expectations of youth may overshadow personal expectations and overwhelm youth (KVDA, 2015). There is also an assumption that whitecollar jobs are best, and little encouragement is offered to youth to take up blue-collar jobs (Kimando, Njogu \& Kihoro, 2012).

\subsection{Relationship between level of education and} business success. According to Wanigasekara and Surangi (2010), owner managers with education and experience in managing business are more capable of finding ways to activate business compared to others who do not have experience and education. Maina (2011) observed that those in self-employment lacked managerial skills and this led to the introduction of entrepreneurship education. According to Turton and Herrington (2012), in South Africa there is a positive correlation between opportunity-driven entrepreneurship and levels of education. Paradoxically, and mostly because of demographic change, the rates of graduate and unemployed youth have also been growing in both developed and developing economies (Kaijage \& Wheeler, 2013). The high unemployment rate that still prevails in the country shows that education in entrepreneurship has had little influence on job creation in Kenya (Njongeri, 2015).

\section{Research methodology}

The study followed a quantitative, nonexperimental, descriptive research approach. The population comprised of all members of the registered youth groups in Kenya. According to the Ministry of Youth Affairs, there were five hundred registered youth groups in Kenya in the year 2012, and twenty five were based in Kibera district. Kibera is a low income, informal settlement in southwest Nairobi, Kenya. With an estimated population of one million housed on less than $2 \%$ of the total municipal residential land (or 3,000 people per hectare), it holds one of the highest population densities in sub-Saharan Africa (Crosson, 2005).

4.1. Sample selection and size. A simple random sampling technique was used to select the groups from which the respondents were drawn. The list of registered youth groups as obtained from the Ministry of Youth Affairs was used as the sample frame. Similarly, respondents were identified from the sampled youth groups by simple random sampling. For the purpose of this study, a sample size of three hundred (300) members (respondents) was drawn from twenty five youth groups in the Kibera district and only two hundred and fifty (250) were returned fully completed giving the response rate of $83.3 \%$. A total of 15 questionnaires were spoiled because the respondents were over the age of 35, and the other 35 potential respondents did not respond despite numerous follow-ups.

4.2. Data collection. A questionnaire was used as the instrument of collecting data and consisted of two sections, namely: Section A which covered demographics and business information, while Section B covered questions that addressed the factors affecting youth entrepreneurship in Kibera. The variables in the questionnaires were mainly based on the themes in the research objectives. Prior to completing the questionnaires, respondents were provided with informed consents to complete in order to ensure that they understand their right in that participation was voluntary. Once the respondents accepted the informed consent, they, then, gained full access to the questionnaires. In instances where filling of the questionnaire encountered difficulties, the researcher adopted interviews. Where an interview was used, the questionnaire formed the basis of the questions asked. In this case, six (6) of the questionnaires that were outstanding had to be completed face to face through this interview method at the respondents' premises to fast track the completion of data collection process. In quantitative research, the survey approach allows for a large collection of data and can be administered face-toface, by telephone or mail. Mail administered surveys have a wide reach, are relatively cheap to administer, information is standardized and privacy can be maintained. Therefore, the questionnaires were sent to respondents via e-mails, and eighteen (18) of them were physically collected by the fieldworker who is based in Kibera. To ensure survey validity, reliability and consistency of the questionnaires, a pilot study was carried out with eight students doing B.Com. Entrepreneurship at the University of South Africa. This group was selected because it is common knowledge that majority of students are within the youth age group, and the piloted students are studying towards entrepreneurship which makes them understand aspects of entrepreneurship education better. The aim of the pilot survey was to determine the scientific correctness of the questionnaires, to note statements that needed clarifications and to establish how long the questionnaires will take to complete. 
4.3. Data analysis. This began with pre-processing of collected data through editing to detect errors and omissions and making corrections. The researcher undertook careful analysis of the questionnaires for completeness, accuracy and consistency with other information gathered. Descriptive statistics was used to test the null hypothesis, and the collected information was coded and computed using OriginPro 9.1.

\section{Findings and discussions}

5.1. Demographics of the sampled youth entrepreneurs' in Kibera. There was an equal distribution of gender in business enterprises that were sampled. This shows that youth in Kibera, both male and female, has equal opportunities when it comes to entrepreneurship activities. In terms of age, most of the youth running business enterprises in Kibera was towards the upper end of youth age which is between $26-29$ years $(n=18.60 \%)$. Only a few tend to start businesses at the age of $18-21$ years $(n=1.3 \%)$, but this number seems to grow drastically when they reach the age of 26-29 years and, exponentially, when they are in the 30-35 years age group. With regard to education, all the target group members had formal education. This is supported by the large number of primary and secondary schools in the region together with government provision of "Free Primary Education". Most of the youth has reached diploma level $(n=15.50 \%)$.

5.2. Type of business operations. Most of the businesses can be scaled as small scale businesses that have a potential to grow. Interaction with most respondents pointed out that they do not have adequate capital to start or grow their businesses to a middle level business enterprise. It was also noted that more women than men operated groceries. An almost equal number of the two genders operated salons and barber shops. A higher percentage (95\%) of all car wash and garages were operated by men. Other business enterprises noted in this research included kiosks, boutiques, butcheries and supermarkets.

5.3. Length of business operation. It was noted that most of the business started have not yet lasted for two years. This indicates that most of the businesses started do not last for a long period. It is perceived that this high rate of business failures is due to youth expecting very high returns in a short duration. Other reasons perceived for this high failure rate include the level of education (Herrington, Kew, Simrie \& Turton, 2011), government policies, provision and access to entrepreneurship education (Herrington, Kew \& Kew, 2009). It was also noted that, as time goes by, the chances of sustaining a business in Kibera also decline. Very few businesses that were started by the youth in Kibera have lasted for 7 to 9 years.

5.4. Revisiting the hypotheses. The statistical procedure used to test the hypotheses of the study was Pearson correlation coefficient. The following hypotheses were tested in this study:

$H_{0}$ (null hypothesis): There is no relationship between provision of entrepreneurship education \& training and the development of youth entrepreneurship.

$H_{0}$ (null hypothesis): There is no relationship between the level of education \& training and the development of youth entrepreneurship.

\section{Hypotheses testing}

In order to determine how the provision of access to entrepreneurship education and the entrepreneur's level of education affect youth entrepreneurship development, a Pearson product moment correlation was computed using OriginPro 9.1. Similar results were obtained when Microsoft Excel 2013 was used. The results were interpreted as shown in Table 1.

Table 1. Interpretation of the correlation coefficient

\begin{tabular}{|c|c|}
\hline Correlation between & Is said to be \\
\hline .8 and 1.0 & Very strong \\
\hline .6 and .8 & Strong \\
\hline .4 and .6 & Moderate \\
\hline .2 and .4 & Weak \\
\hline .0 and .2 & Very weak \\
\hline
\end{tabular}

6.1. Hypothesis one. $H_{0}$ (null hypothesis): There is no relationship between provision of entrepreneurship education \& training and the development of youth entrepreneurship. In order to test this hypothesis, frequencies of Youth Entrepreneurial Development (X) and the provision of entrepreneurship education (Y) were tabulated from the data collection form in Appendix A. Table 2 summarizes results obtained in finding the correlation coefficient of these variables.

Table 2. Correlation between the provision of entrepreneurship education $\&$ training and youth entrepreneurship development

\begin{tabular}{|c|c|c|c|c|c|c|}
\hline Descriptive statistics & $\mathrm{N}$ & Mean & SD & Sum & Min & Max \\
\hline Youth entrepreneurship & 30 & 3.03333 & 0.56283 & 91 & 2.2 & 4 \\
\hline Provision of entrepreneurship & 30 & 2.8 & 0.61476 & 84 & 2 & 3.8 \\
\hline Pearson correlation & & Youth entrepreneurship development & \multicolumn{4}{|c|}{ Provision of entrepreneurship education } \\
\hline Youth entrepreneurship development & Pearson corr. & 1 & 0.75741 & & & \\
\hline
\end{tabular}


Table 2 (cont.). Correlation between the provision of entrepreneurship education $\&$ training and youth entrepreneurship development

\begin{tabular}{|l|c|c|c|c|c|c|}
\hline Descriptive statistics & N & Mean & SD & Sum & Min & Max \\
\hline Youth entrepreneurship development & Sig. & - & $1.26 \mathrm{E}-06$ & & & \\
\hline Provision of entrepreneurship education & Pearson corr. & 0.75741 & 1 & & & \\
\hline Provision of entrepreneurship education & Sig. & $1.26 \mathrm{E}-06$ & - & & & \\
\hline
\end{tabular}

The correlation coefficient obtained was 0.75741 indicating a strong positive correlation between provision of entrepreneurship education and training and development of youth entrepreneurship. This study therefore rejects the null hypothesis (there is no relationship) and accepts the alternative hypothesis. There is a statistically significant relationship between Youth entrepreneurship Development and Provision of Entrepreneurship Education and Training with a 95\% confident that the relationship exists. With the $\mathrm{P}$ value at 0.05 the level of significance is 0.00000126 (or 1,26 E-06). Therefore, the results of this study confirm that provision of entrepreneurship education has a strong positive relationship with development of youth entrepreneurship.

This indicates that the Kenyan government is indeed supporting youth entrepreneurship in Kibera but their efforts, to a certain degree, appear to be less successful which can be attributed to either unwillingness of the youths to take up the opportunities or other factors not considered in this study such as poor communication from government agencies to the youths, high cost of higher learning institutions or long bureaucracies in terms accessing services and registration of the business enterprises. This research therefore suggests that the government should come up with better ways

to disperse information targeted to the youths such as organizing a series of workshops and seminars to the people of Kibera. Better ways to disperse information on government policies and opportunities should also be sought for so that the good ideas and intentions of the government can easily be accessed by the youths.

6.2. Hypothesis two. $H_{0}$ (null hypothesis): There is no relationship between the level of education \& training and development of youth entrepreneurship.

According to Cole (1997), training is a learning activity, which is directed towards acquisition of specific knowledge \& skills for the purpose of an occupation. Armstrong (1999) concurs with Cole that training is a systematic modification of behavior through learning, which occurs as a result of education and instruction. The current Kenyan school system does not put emphasiz on entrepreneurship education that prepares youth to have a basic understanding of how to start and run a business through courses such as financial literacy, marketing and business skills. The high failure rate means that many youth does not qualify for enrolment into further training and education opportunities and, therefore, falls into antisocial behaviors (Herrington et al., 2009).

Hypothesis two tests the correlations between the level of education \& training in Kibera and the development of youth entrepreneurship. Frequencies of Youth Entrepreneurial Development (X) and the level of education and training of the entrepreneurs (Y) were tabulated from the data collection form in Appendix 1 and subjected to Pearson correlation coefficient. Table 3 summarizes results obtained in finding the correlation coefficient of these variables.

Table 3. Correlation between youth entrepreneurship development and level of education

\begin{tabular}{|l|c|c|c|c|c|c|}
\hline \multicolumn{1}{|c|}{ Descriptive statistics } & N & Mean & SD & Sum & Min & Max \\
\hline Level of education & 30 & 2.3 & 0.79438 & 69 & 1 & 4 \\
\hline Youth entrepreneurship developement & 30 & 3.03333 & 0.56283 & 91 & 2.2 & 4 \\
\hline Pearson correlation & & Level of education & \multicolumn{2}{|c|}{ Youth entrepreneurship } & \\
\hline Level of education & Pearson corr. & 1 & 0.06941 & & & \\
\hline Level of education & Sig. & - & $7.16 \mathrm{E}-01$ & & & \\
\hline Youth entrepreneurship developement & Pearson corr. & 0.06941 & 1 & & & \\
\hline Youth entrepreneurship developement & Sig. & $7.16 \mathrm{E}-01$ & - & & & \\
\hline
\end{tabular}

The correlation coefficient obtained was 0.06941 showing a very weak positive correlation between level of education \& training and the development of youth entrepreneurship since the coefficient is next to zero. The study therefore fails to reject the null hypothesis and ultimately accept it. There is not a statistically significant relationship between Youth Entrepreneurship Development and the level of education and training among the youth entrepreneurs within Kibera. Therefore, this study cannot be $95 \%$ confident that the relationship exists.

\section{Revisiting the objectives}

1. Determine the government's provision and access to the entrepreneurship education and training among the Kenyan youth. The 
descriptive statistics results of this study showed that provision and access to entrepreneurship education a strong positive relationship with development of youth entrepreneurship.

2. Determine whether there is a relationship between the level of education, training and development of youth entrepreneurship. Results of this study showed a very weak positive correlation between level of education \& training and the development of youth entrepreneurship, meaning there is no relationship between the two.

\section{Conclusions}

This study investigated factors that affect youth entrepreneurship development in Kibera district in Kenya with specific reference to entrepreneurship education. These factors were provision and access to entrepreneurship education and training, the relationship between the level of education and youth entrepreneurship development. The study found that provision of entrepreneurship education has a strong positive relationship with development of youth entrepreneurship and the level of education has a very weak positive relationship to youth entrepreneurship development. The positive relationship shows that the Kenyan government is indeed supporting youth entrepreneurship in Kibera, though other scholars maintain that the efforts are less successful than expected. This situation is not only unique to Kenya, Likewise, in South Africa programs and investment into youth enterprise development have been unsuccessful. This can be attributed to either unwillingness of the youths to take up the opportunities or other factors not considered in this study such as poor communication channel between the government agencies and the youths, high cost of higher level education or long bureaucracies in terms of accessing services such as registration of the business enterprises. The negative relationship between the level of education and youth entrepreneurship development indicated that youth entrepreneurship does not depend on the level of education attained by the youth. Therefore, this study suggests that any youth, with a little formal or informal education on entrepreneurship, can start and maintain a business.

\section{Recommendations and policy implications}

- The government of Kenya and other institutions offering BDS services should embark on aggressive marketing campaigns in order to increase the awareness of such support initiatives among young people in Kibera. These marketing efforts could include radio, television, billboards, social media, the internet and, most importantly, townships roadshows.

- Further studies on factors affecting youth entrepreneurship development in Kibera should be conducted. These factors are, but not limited to, poor communication channel between the government agencies and the youth, student drop out from schools in both primary and secondary level despite provision of free education, high cost of higher level education and long bureaucracies in terms of accessing services, such as registration of the business enterprises.

\section{Acknowledgement}

Lucy Were (Kenya): Honours student at Unisa.

\section{References}

1. Armstrong, M. (2009). A Handbook of Human Resource Management Practice $11^{\text {th }}$ Ed. London: Kogan Page Ltd.

2. Chigunta, F., Schnurr, J., James-Wilson, D. and Torres, V. (2005). Being "real” about youth entrepreneurship in Eastern and Southern Africa: Implications for adults, institutions and sector structures. ILO SEED Working Paper 72, pp. 1-93. Available at: www.ilo.org/publns. Accessed on 19 August 2013.

3. Chiloane-Tsoka, G.E. and Mmako, N.M. (2014). Effects of migration and immigration on SMMEs: the case study of Diepsloot informal settlement, South Africa, Problems and Perspectives in Management, 12 (4), pp. $377-383$.

4. Cole, G.A. (1997). Personnel management: theory and practice. $4^{\text {th }}$ ed. Letts Educational. London.

5. Crosson, C. (2005). Youth information networks in Kibera, Nairobi, Kenya 2004-2005 Hart Fellow; Duke University.

6. Global Employment Trends for Youth. (2013). A generation at risk. Geneva: International Labor Organization.

7. Gok (2010). The Prevention of organized crimes ACT, 2010. Nairobi: Government printer.

8. Herrington, M., Kew, J. and Kew, P. (2009). Global Entrepreneurship Monitor 2008 South Africa Report. Available at: http://www.gsb.uct.ac.za/files/GEM2008SouthAfricanReport_1_1.pdf.

9. Herrington, M., Kew, J., Simrie, M. and Turton, N. (2011). Global Entrepreneurship Monitor: 2011 South Africa Report. Cape Town: University of Cape Town Graduate School of Business.

10. Kaane, H.L. (2014). Kenya country report for the 2014 ministerial conference on youth employment. Kenya country report: Abidjan.

11. Kaburi, S.N., Mobegi, V.O., Kombo, A., Omari, A. and Sewe, T. (2012). Entrepreneurship Challenges in Developing Economies: a case of Kenyan Economy, International Journal of Arts and Commerce, 1 (4), pp. 264-274.

12. Kaijage, E. and Wheeler, D. (2013). Supporting Entrepreneurship Education in East Africa. A Report for Presentation to Stakeholders.

13. Kanyari, J.W. and Namusonge, G.S. (2013). Factors that Influence the Kenyan Youth Entrepreneurs Towards the 
Youth Enterprise Development Fund: A Case Study Of Gatundu South District, Kenya, International Journal of Education and Research, 1 (5), pp. 1-22.

14. Kshetri, N. (2011). Institutional and economic foundation in Africa: An overview, Journal of development entrepreneurship, 16 (1), pp. 9-35.

15. KVDA. (2015). Empowering the community for a healthy and gender sensitive approach to social participation. VIHIGA COUNTY, Western Kenya. 4th -25th April 2015.

16. Kenya National Youth Policy. (2012). Ministry of Home Affairs, Heritage and Sports. Available at: http://www.africanchildforum.org/clr/policy\%20per\%20country/kenya/kenya_youth_2012_en.pdf.

17. Kilele, A.K.M. (2008). Kenya National Bureau of Statistics (KNBS). Kenya facts and figures 2008. Available at: http://www.knbs.or.ke/index.php?option=com_phocadownload \&view=category\&id=20\&Itemid=1107. Accessed: 2015-10-01.

18. Kimando, L.N., Njogu, G.W. and Kihoro, J.M. (2012). Factors Affecting the Success of Youth Enterprise Development Funded Projects in Kenya; A Survey of Kigumo District Muranga County, International Journal of Business and Commerce, 1 (10), pp. 61-81.

19. Mahinda, W. (2004). What is affecting the supply of youth entrepreneurs in Kenya? Paper for Expert Group Meeting on Strategies for Creating Urban Youth Employment, 21-25 June 2004, Nairobi, Kenya.

20. Maina, S.W. (2012). Factors influencing the development of youth entrepreneurship in Ongata Rongai Township. Master of Arts Thesis. Nairobi: University of Nairobi. Available at: http://erepository.uonbi.ac.ke:8080/xmlui/handle/123456789/10886. Accessed on 25 September 2013.

21. Maxwell, J.R. (2002). Recommendations for connecting West African youth to entrepreneurship and small business through a multiple level strategy: Paper presented at United States Association for Small Business and Entrepreneurship International Conference, Reno, Nevada U.S.A., January 17-20, 2002.

22. Mazwai, E.T. (2010). The effectiveness of local business service centres in small business development: A case study of Gauteng province, South Africa. Published D com Thesis. Pretoria. University of Pretoria.

23. Moraa new hope foundation. (2015). Challenges facing Kenyan youths. Available at: http://www.moraafoundation.org/challenges-facing-kenyan-youths. Accessed: 2014-07-17.

24. Mwangi, I.W. and Shem, A.O. (2012). Social capital and access to credit in Kenya, American Journal of Social and Management Sciences. Available at: http://www.scihub.org/AJSMS.

25. Njongeri, W. (2015). Influence of entrepreneurship education in developing entrepreneurs in Kenya: The case study of Jomo. Kenyatta University of agriculture and technology.

26. Njoroge, C.W. and Gathungu, J.M. (2013). The effect of entrepreneurial education and training on development of small and medium size enterprises in githunguri district - Kenya, International Journal of Education and Research, 1 (8).

27. Okirigiti, C.A. and Rafey, M.A. (2015). Challenges Facing Youth Entrepreneurs in Slums in Kenya: A case of Kisumu Ndogo Slums in Eldoret Municipality Kenya, European Open Business \& Management Journal, 1 (1), pp. 1-10 Available at: http://eurpub.com/Journals.php.

28. Omondi, P. (2013). Youth Enterprise: Inhibiting Factors and Opportunities. Available at: http://ems.uonbi.ac.ke/node/1345. Accessed on 03 March 2013.

29. Rori, A., Bunei, J. and Mwenzwa, E. (2011). Revitalizing youth entrepreneurship in Kenya: A Deliberate Training Curriculum, International Journal of current research, 3 (10), pp. 121-125.

30. Sagwe, J. Gicharu, S. and Mahea, T. (2011). A Study on Youth and Women Entrepreneurs' Preparedness in Kenya: A Case Study of the Kenya Youth Enterprise Development Fund.

31. Schoof, U. (2006). Stimulating Youth Entrepreneurship: Barriers and incentives to enterprise start-ups by young people, International Labor Office, Geneva, Switzerland.

32. Simiyu, J. and Sambu, L. (2012). Nature and Type of Government and NGO Interventions in Curbing Unemployment and Underemployment of Urban Youth in Kenya, Journal of Emerging Trends in Educational Research and Policy Studies, 3 (5), pp. 730-736.

33. Statistics South Africa. (2014). Statistical release. Quarterly Labor Force Survey, Quarter 2. Pretoria. Available at: http://beta2.statssa.gov.za. Accessed on 13 September 2014.

34. Turton, N. and Herrington, M. (2012). Global Entrepreneurship Monitor: 2012 South Africa Report. Cape Town: University of Cape Town Graduate School of Business.

35. Valerio, A. Parton, B. and Robb, A. (2014). Entrepreneurship Education and Training Programs around the World: Dimensions for Success. World Bank. Washington DC.

36. Wanigasekara, W.M.S.K and Surangi, H.K.N.S. (2010). Impact of level of education and business experience on business success among small retail owner managers in Sri Lanka. Available at: www.kln.ac.lk/fcms/.../dccs/Microsoft\%20Word\%20-\%20ENP001.pdf. Accessed on 18 December 2015.

37. Zepeda, E. (2013). Kenya's Youth Employment Challenge. Discussion paper. United Nations Development Program. New York. 